\title{
The Construction Model of Inculcating Principal Humanistic Values in Forming a Characteristic School Environment
}

\author{
Effendi, Yulius Rustan ${ }^{1 *}$, Bafadal, Ibrahim ${ }^{2}$, Sudana, I Nyoman Degeng ${ }^{3}$, Arifin Imron ${ }^{4}$ \\ ${ }^{1}$ Doctoral Program Student, Educational Management Department, State University of Malang, Indonesia. \\ E-mail: fendiribut.265@gmail.com \\ 2 Prof., Dr (Lecturer), Department of Education Management, State University of Malang, Indonesia. E- \\ mail: ibrahim.bafadal.fip@um.ac.id \\ ${ }^{3}$ Prof., Dr. (Lecturer), Department of Educational Technology, State University of Malang, Indonesia. E- \\ mail: sudana_daniel@yahoo.com \\ ${ }^{4}$ Dr. (Lecturer), Department of Education Management, State University of Malang, Indonesia. E-mail: \\ imron.arifin.fip@um.ac.id
}

\begin{abstract}
This research described the fundamental inspiration behind the implementation of a humanistic approach to the principal's leadership and the steps of the principal's humanistic approach that have an impact on optimizing the implementation of the program for strengthening character education. This research used a qualitative approach, a case study design. The data collection was performed through in-depth interviews, participant observation, and documentation studies to achieve the research objectives. Data analysis used a modified analytic analysis method. The level of credibility, transferability, dependability, and confirmability was the basis of data validity. The research findings explained that personal excellence (integrity, wholeness, and self-authenticity) and the humanistic spirituality of inspirational figures inspired the principal's humanistic approach. In addition, the application of the principal's humanistic approach had adequate impacts on optimizing the implementation of a program for strengthening character education and influenced the strengthening of the student's character. Through the principal's humanistic approach, school becomes an environment for empowering the character of the students.
\end{abstract}

Keywords: humanistic values, principal's leadership, a character school environment

\section{Introduction}

A program for strengthening character education by the Indonesian Ministry of Education has revitalizing character education in Indonesia since 2010. Although the revitalization of national education policy applies, strengthening character education has not been implemented optimally at the school level. Based on the findings of Wahjosumidjo (1999); Danim (2007); Danim \& Suparno (2009); Koesoema (2016); Ministry of Education and Culture (2017), the failure to carry out the program for strengthening character education in schools is caused by two weaknesses of the principal's leadership, namely; first, the principal has not yet found an approach model that humanizes human. Several indicators of weakness in the principal's approach; a) does not humanize followers, because it only focuses on the leader, glorifies the leader, and ignores the principle of human equality, ignores the maturity and personality of followers; b) based on the concept that the leader runs power over followers, which was carried over since the authoritarian Suharto regime; c) result-oriented and regards followers as followers instead of humans, because their morality needs encouragement; d) emphasizes the leader, followers are only the result of leader's behavior; e) leader fails to explain the personal development of followers or their well-being; f) leader and followers are not on the same level, and there is a clear hierarchy between them As a result, followers only wait for the leader's order (top-down). Second, the principal has not been able to design an education that means humanizing humans with character (Dewantara, 1977). As a result, school principals are less innovative in implementing the 2013 Curriculum which was 
conceptualized by the Indonesian Ministry of Education; the strengthening of character education has not yet received a central position in the school curriculum and is insignificant, so that students' self-development becomes stunted, there is no integration of character values in learning, school environment does not become an environment of character empowerment, active participation of parents and the community in supporting the formation of student's character in school is very low.

Responding to the weaknesses of the principal's leadership, it is crucial and urgent for school principals to use a humanistic approach as a step in building the student's character (Veugelers, 2008; Ministry of Education and Culture, 2017). It is timeconsuming since the humanistic approach is considered new to be implemented by school principals in Indonesia (Said, 2007). Most school principals in Indonesia use the humanistic approach label, but there is no apparent leadership approach in its practical application, thus confusing the followers to join in.

Although not all school principals in Indonesia can apply the humanistic approach, we found two principals of private schools in Malang City, East Java, Indonesia, namely the Catholic Junior High School Santa Maria II and the Catholic junior High School Sang Timur who have implemented the humanistic approach effectively in recent research. The two principals adopted the humanistic approach based on self-excellence (integrity, wholeness, self-authenticity) shows in an attitude of openness, existentialism in a new experience, consistency, flexibility, creativity, and constructive. In addition, they were inspired by the humanist spirituality of the founding fathers of the spiritual congregation as the spirit that drives the humanistic values of all members of the school community. It is also shown in the performance of the two principals who humanize their followers (working with no pressure, respect, and care for followers). Eventually, the followers join in a framework that characterizes humanistic values, which has an impact on optimizing the implementation of a program for strengthening character education.

Based on the inspiration that underlies the humanistic approach of the two principals, this research focused on describing the reasons of the two principals, how they think, introspect, behave, act, interact, and most importantly lead, and what principles they use. In this research, the researchers identified themes, categories, and dimensions that explained the humanistic approach of the two principals, and arranged this constituency into a framework that comprehensively explained the performance of the two principals to meet the research objectives.

The contribution of this research is to position humanistic values derived from selfexcellence and the humanist spirituality of the sisters who founded the religious congregation, as a fundamental inspiration that supports the humanistic approach of the two principals. In addition, in the light of recent research, the results of this research are recommended for all principals in the Education Office of Malang City, East Java and throughout Indonesia, they need to use the humanistic approach model in carrying out leadership roles, because it has been proven effective in optimizing the implementation of program for strengthening character education in schools.

\section{Literature Review}

\section{Humanistic Values of Principal Leadership}

The presence of a leader in an organization is significant in handling changes. Changes do not occur due to the leader's actions towards people but along with people (Colbert, Nicholson, \& Kurucz, 2018). In this context, the presence of a leader supports the relationship and dialogue between leader and followers in several dimensions of humanity, such as; followers find meaning and vision in the workplace, persuasive 
communication, participation and autonomy, fair treatment, constructive responses, goal development and personal growth, becomes a role model (Peus \& Frey, 2009).

The role of the principal in dealing with the advancement in education today, as is the case in Indonesia, only carries out an administrative role and does not yet determine a leadership model (Wahjosumidjo, 1992). Even though Indonesia has passed the reform era, after the end of the authoritarian Suharto regime, the indoctrination system of an educational leader is still perceived (Mutrofin, 2007; Koesoema, 2010). Wait for instructions and orders from superiors (top-down) followers work under a leader's pressure, work to get a reader's attention, work after receiving orders, work with hypocrisy, become a reality of bad leaders (Danim \& Suparno, 2009; Endah, 2012;). The role of such leaders stunts the existence of follower's humanity as an equal and perfect being as well as becomes a barrier to the growth of human inclusiveness (Mutrofin, 2007; Koesoema, 2016; Kasali, 2016).

This condition urges principals to position themselves as a wise person in applying the leadership model. The principal's discretion is judged based on; a) moral imagination, in the form of the ability to see ethical problems and consequences in circumstances (Werhane, 2002, 2008); b) understand the system or perspective about a situation that is quite realistic and holistic (Senge, 1990; Werhane, 2008); c) aesthetic sensibility or the ability to see and assess design and aesthetic problems and consequences in a situation (Veugelers, 2007).

A leader must have moral imagination because managing and organizing education are human activities so that it is firmly and inseparably embedded in moral values and problems. Human activities in the educational environment always occur in the context of public interests and broader situations, hence integrally related to ethical considerations. Therefore, the priority in managing education is to look at human activities, full of emotions, rationality, spirituality, and care, as well as relationships with others, and how to create value in positive competition in education (Waddock, 2016).

Humanize the system, integrating ethics and responsibilities, are parts of inseparable unit, and bringing humanities into educational leadership is significant for future leaders. In this context, both the human dimension and the professional dimension are equally important. Therefore, both professional and personal lives integrate into the existence of a leader. Thus, moral imagination explicitly opens the strategic steps of an approach for an educational leader on the act of giving meaning and direction to the lives of all school components (Baumeister, 1991). Leaders have a moral obligation to live a life and protect people (Veugelers, 2008; Pirson \& Amann, 2010). These were confirmed also by Werhane (2002, 2008); Waddock (2016); Dierksmeier (2016); Melé (2016) that the educational environment should develop aspects of the humanistic approach, including appreciation and unconditional recognition of the values of human dignity of all school components, ethical reflection integrated into decision making, normative legitimacy to take action and decision in educational organizations; school does not only target academic achievement, but also consider the value of human character, the existence of transparency, truth, and humanistic communication through the similarity of words and actions. These components are an integral part of moral imagination.

Emphasis on moral imagination is as a model approach that realizes organizational members as individual human beings; which explains, reflects and respects the subjectivity, relationality, individuality and personality of members; acting in relation to self-determination and human dignity of these people; and aims to build a constructive community of people and on human growth (meaning welfare, self-actualization and selftranscendence of organizational members) as the goal (Giustiniani, 1985). Thus, the 
humanistic approach is meaningful because it ignores leaders-centralism and deificationleaders as well as prioritizes humanitarian ethics (Waddock, 2016). By placing humans at the center of leadership research, this research can make a far more meaningful contribution to leadership in practice, and help educational organizations realize human potential and increase social capital in building trust, integrity, harmony, and morality in followers.

\section{Humanistic Principals Shaping Character Environments}

Indonesia in the post-reform era has experienced a multidimensional crisis, specifically the moral decline in the economic, political, and education sectors (Kasali, 2017). Moral conflict causes moral deviations among students in Indonesia, such as; intolerant attitudes, student fights, drugs, promiscuity, cheating, stealing, skipping school, dressing immodestly, not ethical in speaking, decreasing national cultural values (Koesoema, 2010; Endah, 2012; Ministry of Education and Culture, 2016). The moral decline among students can lead to a judgment that schools, parents, and society has failed to prepare the future generation of the nation. Responding to this fact, schools need to proactively change the new paradigm in the direction and purpose of education, namely on the formation of students' knowledge and character. School responsibilities in this regard is to optimize program for strengthening character education in line with the Republic of Indonesia Government Regulation number 87 of 2017 on Strengthening Character Education, chapter I, article 1, which emphasizes that " program for strengthening character education is a pedagogical activity that integrates heart, feeling, mind, and body and is implemented through a collaboration between the internal components of the school, parents, and society in line with the drive to develop mental through the National Mental Revolution Movement".

This Government Regulation needs to be implemented in schools through intensive coordination with all components of the school, including the role of principal. The significance of school principals in Indonesia has long declined so that it can threaten the existence, sustainability, competitiveness, and progress of the quality of education (Wahjosumidjo, 1992; Mutrofin, 2007). It clearly generates a negative stigma on the roles of the principal. The negative stigma to the role of the principal does not need reactive responses because it is possible that the stigma does indeed reflect the truth of the substance of the principal's role. The best response is to reform, formulate, and change the principal's approach model. The change in question is revising the conventional approach to a humanistic approach to empower the potential of educational institutions to become a reliable agent in escorting, delivering, and realizing the success and improvement of the educational institutions' quality.

The principal's contribution as the key to success has four key elements of the humanistic approach framework, namely; confidence in progress (human capacity for development and improvement); reasons (including justified knowledge, learning, and beliefs); inclusiveness (universal acceptance into dialogue with all people who are able to reason); and focus on individualism (the idea that each person is inherently valuable, regardless of the collective identity determined by ethnicity, religion, race, and class (Nida-Rümelin, 2009).

In the context of strengthening character education, according to Cowan (2007); Aloni (2011); Zain (2015); Koesoema (2016); Colbert \& Kurucz (2018), the principal's humanistic approach is applied to 1) make a well-organized organization so that it remains relevant to the interests of members in addition to the interests of the overall organizational progress; 2) design a program for strengthening character education that 
includes: (a) personal development activities; (b) character learning activities through the establishment of joint policies relating to the standard set of core values of school characters, designing learning tools, applying character learning models, and evaluating character learning; (c) activities in the school environment, and (d) activities in the community environment; 3) close and harmonious interaction between leader and members to promote unity and to live in harmony; 4) build partnerships by avoiding oppressive working conditions through maintaining work situations that build selfconfidence; talking less and doing more; reducing the habits of anger, jealousy and envy, and motivating teachers to work more effectively instead; avoiding the habit of blaming teachers and be able to correct the their mistakes to prevent boredom at work, but instead must be able to create a working atmosphere that makes teachers interested and comfortable doing their work based on a noble value system, so all elements in the school are willing, without coercion, to participate optimally in achieving school's ideal goals; 5) building partnerships between school, the government and community through habituation programs in conditioning the school environment with character. In this case, the contribution of principal in the collaboration will make the school as an environment for sowing virtue, a place for growing and rooting the superiority of moral values and intelligence of faith and thoughts (mutual respect, virtue ethics, self-orderliness, and appropriateness of words and actions); 6) paying attention to the conscience of members with all their hopes, needs, and abilities.

\section{Methods}

\section{Research Design}

This research used a descriptive-analytic qualitative research design to collect data and describe it in written or oral, then arranged in sentences based on interviews with informants. The presence of researchers was a measure of success in dissecting in several cases. The researcher acted, with the help of others, as a key instrument in collecting data from people actively involved in the two schools examined (principals, teachers, staff, students, parents, school committees, communities, and school foundations). The sampling technique in this research, the purposive sampling, was applied using the chimney technique. The data collection process started from broad data collection then narrowed down according to the focus of the research. During one year, this research took place in two schools in Malang City, East Java, Indonesia: Catholic Junior High School Santa Maria II, and Catholic Junior High School Sang Timur.

\section{Data and Sources of the Data}

The sources of the data were from primary data obtained from key informants in the form of words of oral or verbal language and from secondary data in the form of documents as a complement to the primary data. The selection of informants used several techniques; first, purposive sampling, selecting informants who master information in-depth, reliable as a valid data source. Data sources used in the research were 40 informants, including: 1 school principal (2); 5 teachers (10); 3 employees (6); 3 students (6); 2 students' parents (4); 2 school committees (4); 2 alumni (4); 1 school supervisor (2); 1 lecturer as a consultant. Second, snowball sampling, looking for information continuously from one informant to another so that the data obtained is getting more in number and more complete and in-depth, and stops when the data obtained is considered saturated. We directly observed events or activities at school. 


\section{Data-analysis Techniques}

The technique used in data analysis was working with data through the process of systematically searching and organizing interview characters, field notes, and other materials collected by the researchers. The analysis was continued by analyzing data, arranging, dividing into units, synthesizing, looking for patterns, finding what was meaningful and what was examined and reported systematically. At this stage, data analysis was performed and used in such a way as to obtain the truth of the data to answer the research focus. The inductive method was used to manage qualitative data. The inductive method allowed the arrangement of data in the form of data condensation through the process of selecting, focusing, simplifying, abstracting, and changing the data appearing in comprehensive research from written field notes, interview transcripts, and documents. Then, the data was presented, allowing conclusions and actions made. Temporary conclusions based on matrices had been made to find patterns, topics or themes in accordance with the research focus.

\section{Checking the Validity of Data}

The validity of the data in this research used several measures, including first, a measure of credibility (level of trust). The purpose of data credibility is to prove the data suitability with the facts in the research. To establish the validity of the data, the researchers used the following inspection techniques: 1) extending involvement, thus allowing an increased level of confidence in the data collected. By extending involvement, obtain accurate information and subject trust. Therefore, the researchers expanded participation explained in the research background. 2) Perseverance in observation means that researchers in detail looked for and found characteristics and elements in situations that were highly relevant to the problem under the study. 3) Triangulation facilitated data checking by comparing it with something else. This was performed in several stages, including: (a) source triangulation, performed by means of: (1) comparing observation data with interview data; (2) comparing what was said in public with what was said privately; (3) comparing what people say about the research situation with what they say all the time; (4) comparing one's circumstances and perspectives with other people's views; (5) comparing the results of interviews with the contents of related documents. (b) Triangulation method by checking the level of confidence in the research findings based on several data sources with the same method. (c) Triangulation theory compared facts with one or more theories as a comparative explanation. 4) Peer examination through discussion with peers. 5) Analysis of negative cases by collecting examples beyond the patterns and trends of information collected and used as a comparison. 6) Examining members, to check whether the data recorded and interpreted by the researchers was appropriate, and the key informants recognized the truth. Second, performing transferability through detailed research reports that referred to the focus of the research. Third, dependability was performed to check or evaluate the accuracy of researchers in conceptualizing data constantly. Fourth, confirmability was performed through a test to assess the research results, mainly related to the description of research findings and discussion.

\section{Results and Discussion}

\section{Reasons for the Principal of Implementing Humanistic Values}

In connection with the background of the application of the humanistic approach by the two principals, a figure of the findings of the humanistic approach model applied in the 
implementation of the program of character education strengthening in schools was presented.

Figure 1. Model of Humanistic Approach Principal

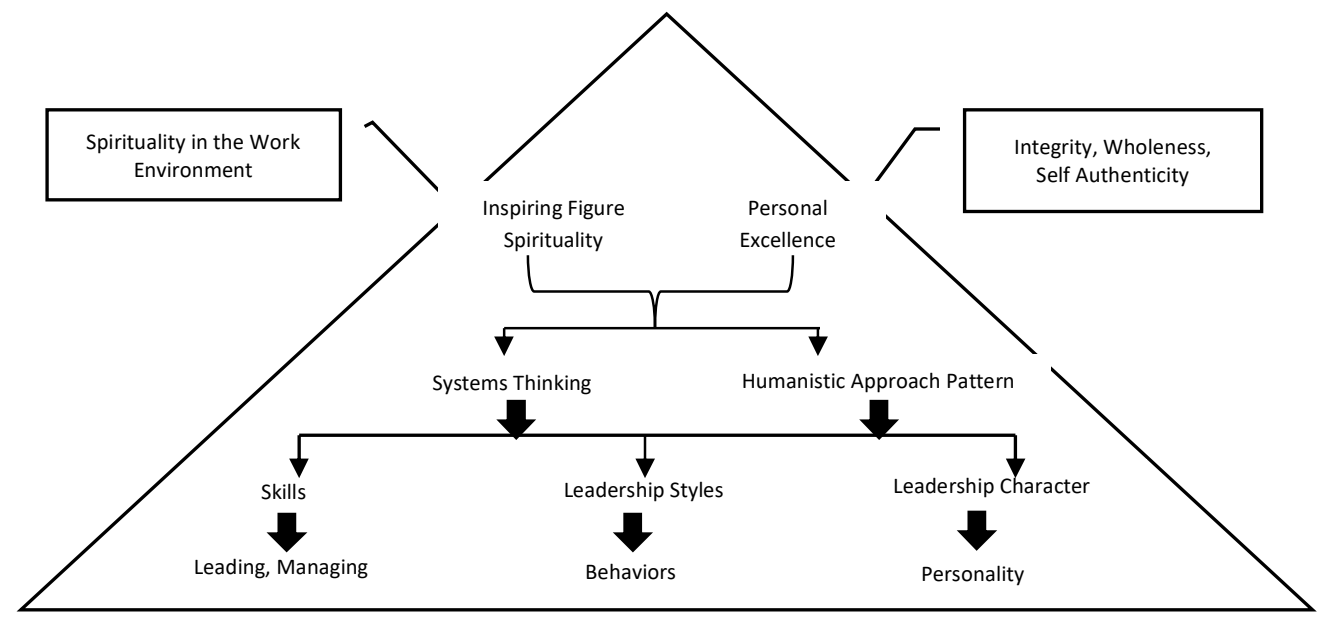

Source: modification based on the results of interviews with key informants and from Sass (2000) thinking; Handbury (2001); Daniels, Nathanson, Mashalla, Petracca, Desmond, ... \& O'Malley, (2013).

Based on Figure 1, the two principals at Catholic Junior High School Santa Maria II and Catholic Junior High School Sang Timur implement a humanistic approach that is as unique and distinctive. It is said to be unique and distinctive because, as members of the Catholic religious congregation, the two principals showed personal excellence (integrity, wholeness, authenticity of self) that appears in an attitude of openness, existentialism in new experiences, consistency, flexibility, creativity, and constructive (Rogers \& Freiberg, 1994). The aspects of personal excellence of the two principals support the humanistic approach principles, as stated by Peus and Frey (2009); Barrick \& Mount, (1991): a) open, so followers (teachers and employees) can find meaning and vision as educators, followers are entitled to transparency through open information and communication, b) supportive, accommodating, empathetic, gentle and kind, c) encouraging participation and autonomy among all team members, d) upholding a sense of justice, e) providing constructive feedback, f) jointly developing goals and personal growth and function as a role model.

In the current era of advancement in education, the role of leaders is crucial in achieving changes, and we must recognize that the achievement of changes is the result of joint activities between leader and followers (Blanch \& Zigarmi, 2001; Aktouf and Holford, 2009). Leader is not only identified by leadership style, but also by aspects of personality, including awareness of oneself and others, and appreciation of diversity, flexibility, and paradoxes (Handbury, 2001). Recent studies have shown that personality traits of a leader influence the work performance of subordinates in general (Blickle et al., 2015; Leutner et al., 2014). Hogan \& Bensen (2009) validated the empirical relationship between personality, leadership, and organizational effectiveness through the leadership value chain. Thus, a leader's humanistic approach provides an effective and powerful way through personality colors (Haynes et al., 2015). The leader personality dimension determines the aspects of a decision and determines whether the decision making is centralized or not (Byrne et al., 2015).

In addition to personal excellence, the fundamental inspiration that encouraged the two principals to use a humanistic approach was because of the drive to revive the humanistic spirituality of the founding fathers of the congregation who ran the schools. At 
Catholic Junior High School Santa Maria II, the appreciation of humanist spirituality is inspired by Sister Julie Billiart (Sister of the founder of the congregation), that is "loving our fellow humans as the image of Allah." Sourced from the Bible: "So God created mankind in his own image, in the image of God, he created them; male and female he created them" (Genesis 1:27 New International Version). Humanistic values that are raised by the principal including; democratic spirit, solidarity, social sensitivity, pluralistic brotherhood, tolerance, dialogue, respect for human rights, and respect for life. School vision implements these humanistic values; "Realizing a quality, faithful, related, knowledgeable, and cultured school through the appreciation of Christian virtues; love, truth, justice, peace and the integrity of creation."

At Catholic Junior High School Sang Timur, the appreciation of humanist spirituality is inspired by Ms. Clara Fey (founder of the congregation) through her longing for "Abide in Me." Sourced from the Bible: "Remain in me, as I also remain in you. No branch can bear fruit by itself; it must remain in the vine. Neither can you bear fruit unless you remain in me." (John 15:4 New International Version). Humanistic values that support the principal's approach are to accept others as a learning community, in an atmosphere of brotherhood, family, and joy with no pressure. Implementation in the vision of the school; "The realization of a superior, accountable school in competition with the spirit of true brotherhood, kinship, joy, and simplicity to develop into a whole person."

The relationship of spirituality in the workplace and leadership has become increasingly important, thus attracting much attention in the last decade (Strack et al., 2002; Robbins, 2002; Fry, 2003). The dimension of humanist spirituality brought to life by the two principals is a form of certain work feelings that energize action (a moving spirit) (Dehler \& Welsh, 1994). This dimension of humanist spirituality is the spirituality in the work environment, not spirituality in the full belief system (Sass, 2000). Thus, spirituality at work can be objectively explored and studied scientifically and applied by stakeholders (Paloutzian, 1996); Cavanaugh (1999); Ashmos \& Duchon (2000). In relation with a humanistic approach, humanist spirituality at work can enhance organizational learning (Bierly et al., 2000), integrate and develop communities (Cavanaugh et al., 2001), serve the needs of others at work, and build shared commitment ( Khanna \& Srinivas, 2000), and revive expressions of compassion, wisdom, and harmonious communication that oppose all egocentric, sociocentric, or anthropocentric (Maxwell, 2003) forms.

Reviving spirituality in the work environment strongly supports the strengthening of character education, because it refers to the act of integrating human mind, body, and soul (Mitroff \& Denton 1999; Ashmos \& Duchon, 2000; Ministry of Education, 2017) as a natural desire to find meaning and purpose in life. In this context, the principal who revives humanistic spirituality in the school can turn the school from just activities driven by vision and mission to a place in which individuals and collective spirituality are encouraged and spiritual development is integrated into daily work life (Konz \& Ryan, 1999). Thus, the principal's humanistic approach driven by self-excellence and humanist spirituality forms the mindset that: (1) a person's life has meaning, purpose, and makes a difference, (2) a person is understood, respected, and accepted without conditions. 3) commitment, ethical reflection in decision making, and normative legitimacy through joint action influence the effectiveness of education in which human welfare, social responsibility of education, and school institution performance do not only coexist but are also maximized (Fry \& Slocum 2008; Werhane, 2002, 2008). These three dimensions of the humanistic approach are an integral part of moral imagination (Werhane, 2002, 2008), which aims to examine the consequences and ethical implications of school interests, 
interpersonal relationships, and society to design learning programs that focus on the formation of student characters (Patteron, 1987; Dohmen, 2003; Pirson, 2017; Koesoema, 2016).

\section{Principal's Constructive Action in Forming a Character Environment}

In implementing a program for strengthening character education, the two schools referred to guidelines directed by the Indonesian Ministry of Education and Culture, which includes; personal development activities, class activities, activities in the school environment, activities in the community environment (Ministry of Education, 20017). Personal development programs were carried out through several activities, such as: a) regular school activities, including: cleaning classes and toilets, holding the flag ceremony; b) spontaneous activities, including: disposing garbage properly, not making noise in class, not doing violence, being polite, not stealing, dressing modestly; c) exemplary activities.

The humanistic approach of the school principal's leadership in self-development programs is based on the awareness that humans are perfect, and require intrinsic aspirations to actualize themselves (Maslow, 1971; Nemiroff, 1992). This is demonstrated through the humanistic approach steps of the principal, such as: (1) collaboration with all school components who directly involved in decision making, guiding and directing student behavior, (2) building a shared commitment in an exemplary behavior, (3) creating an atmosphere of intimacy in communication, (4) self-control, not getting annoyed with the teachers, employees, and students easily; (5) providing counseling for students who have problems lovingly. (Cowan, 2007).

In this context, a leader needs to realize that success is not due to the work of the leader, but the collaboration of leader and followers (Blanch \& Zigarmi, 2001). Also, exemplary behavior becomes the standard of trust and participation of followers to the leader (Wahjosumidjo, (1992); Mutrofin (2007); Cowan (2007). It is important to understand that a leader does not need to build a gap from followers, but sees followers as equal human beings, having the same personal and social dependency. So, it is necessary to establish persuasive communication (Danim \& Suparno, 2009; Acevedo, 2012; Dierksmeier, 2016). In teacher and student mentoring activities, they jointly develop personal growth and realize that all human beings are basically perfect, so they need selfcontrol to respect each other in the process of mentoring (Dierksmeier, 2016; Ministry of Education, 2017). Thus, humanistic values, which are formed in the principal, such as: understanding teachers, employees, students, parents, school committees, school supervisors, the community as human beings, so that it is necessary to respect their subjectivity, relationality, individuality and personality; and acting with the aim of jointly building the community and human growth (welfare, self-actualization) as the ultimate goal (Aloni, 2011; Mele, 2016; Dierksmeier, 2016).

Strengthening character in integrated classroom activities through learning activities and classroom management requires collaboration between school principal, teachers, students, parents, and school supervisors (Ministry of Education and Culture, 2017). In this activity, the humanistic approach steps of the two principals included: (a) together with teachers, staff, school committee, and students' parents, supervisors, and lecturer as the consultant for designing learning tools that contain character education. 2) Offering parents to share practical knowledge of moral life to the student, and the school set the time. 3) Together with subject teachers supervising "brotherhood-pedagogical", by (a) the teacher and the principal take turns presenting subtopics from the same theme; (b) the teacher is asked to deliver all the material, and the principal together with students make 
conclusions accompanied by the inculcation of character values, or vice versa; (c) the teacher and the principal jointly present the subtopics, students are asked to submit conclusions accompanied by reflections on the content of character values contained in the material discussed. 4) Together with a subject teacher supervising "pastoral environment," by presenting a school supervisor and two parents of students. Supervision is carried out in outdoor, and learning material is given together, discussed together, and makes conclusions together. 5) In applying good and clear management, the humanistic approach of the two principals appears in (a) Building a shared commitment termed "bona fide" which means with a good and trustworthy purpose. That is, in managing the classroom, the teacher's attitude must be goal-oriented, and the teacher must be able to be trusted by students. It shows through attitude; inviting students to listen toward the learning, respecting the opinions of friends, ethical ways of asking questions, creating a comfortable classroom environment, learning from one another (peer tutors), guiding students with love. (b) Building a shared commitment to realizing "utilitatem" (common good). Through this principle, in managing classrooms, teachers need to foster individual freedom and relationality, as well as respect for the free initiative, dialogue, participation, cooperation, and maintaining harmony.

In addition, in the learning activity, teacher as a facilitator applies learning models developed by Stiefel (1975); Gage and Berliner (1991); Rogers \& Freiberg (1994); De Groot (2011), such as: a) Building students' independence in learning by designing unstructured learning models and directing students to arrange them according to their own thinking concepts, making task choices for students to work on, studying together and guiding fellow friends with their knowledge, designing learning models based on problems raised by students. b). Exploring students' learning characteristics by encouraging students to discover values contained in the material that has been stated by students. c). Building interpersonal character through open learning, responding to students' emotions, encouraging interests by asking questions to satisfy students' curiosity, avoiding mental stress. d) Building communicative character in oneself, through dialogue and open discussion, appreciating students' conversation in expressing opinions, e) Building social character by giving responses or feedback in the learning process. f) Conditioning learning spaces and learning designs that position students as learning resources and teachers as facilitators. g). Building character skills in learning by designing various learning designs that are active, creative, and innovative that can be developed by the students themselves.

Reviewing the steps of the humanistic approach of the two principals in-class activities, it clearly shows how the principal built relationships that led to positive morale orientation, because teachers are considered capable of self-regulate, aligning moral values with action (DeCavalho, 1991; Robinson et al., 2000). The principal's humanistic approach that entrusts teachers integrates character education in classroom activities, postulates the nature of holistic education because it combines the educating process with human development (Flake, 2000; Davila \& Elvira, 2012). Building humans in the concept of humanistic pedagogy, placing school as a field for student character development, and assessing that the purpose of learning is to interpret relationships with self, school environment, family, and society (Koesoema, 2015; Gage \& Berliner, 1991; Jingna, 2012).

Furthermore, to build a positive school culture, the two schools program various types of extracurricular activities, such as: organizing recollection, retreats, spiritual camping, eucharistic celebrations, confession of sins, providing an honest canteen, taking choirs in the church, initiating solidarity actions to help friends who are economically weak, raising fund for orphanages, running democracy electing school administrators, 
opening family dialogues with students' parents, looking for donors to finance underprivileged students, cooperating with alumni associations to finance students or parents who are sick and underfunded, making contributions to the deceased family members of students or teachers, forming blood donor groups.

In optimizing this program, the humanistic approach steps taken by the two principals were: (1) realizing the joint decisions contained in the school's strategic plan to organize the programmed activities; (2) entrusting the work team to work in accordance with the area of responsibility; (3) fostering a spirit of cooperation between work teams; (4) creating persuasive communication both inside and outside the school environment; (5) supporting and getting involved in every activity implementation; (6) living and developing the values of faith; (7) building self-sensitivity for solidarity and favoring those in need; (8) promoting the spirit of democracy to reach mutual agreement; (9) inviting alumni to discuss school development, and student conditions; (10) fostering values of honesty; (11) conducting joint evaluation in accordance with mutual agreement, to reflect and internalize the meaning of each activity performed.

Based on the description of the strategic humanistic approach steps of the two school principals, in building positive school culture, humanistic values emanate clearly. This fact reflects in attitudes such as building cooperation, mutual respect, responsibility, persuasive communication, solidarity, self-sensitivity, and compassion in every action. These humanistic values shape a positive school culture (Nemiroff, 1992; Aloni, 2011; Koesoema, 2016; Ministry of Education, 2017), in line with the inspirational humanistic spirituality of the founding fathers of the congregation who manage the school, namely "loving fellow human beings as the image of Allah" and "abide in me". These values are philosophies that give meaning and recognition of the dignity and value of every human being in the school environment (Westheimer, 2011). In this context, the principal's humanistic approach in building a positive school culture becomes the foundation of a holistic-humanistic education (Nava, 2001). The school environment is a character learning environment, a place where students are welcomed into unique personal differences, a tolerant life, and mutual respect because they have unique physical, emotional, intellectual, and spiritual abilities (Sahenk, 2010).

Activities in the community environment are applicable in the form of a) "ad infinitum" activities (up to infinity), meaning that educational activities are not limited to the school environment, but are ongoing with the families of students. It is performed by visiting the students' homes. This activity is scheduled every Sunday and arranged by the head of the public relations work team. b) Building the sensitivity of "amor vincit omnia" (love conquers all) by giving scholarships and providing a dormitory for free to underprivileged students; b) establishing cooperation with the police to provide material about the dangers of drug use, and orderly traffic. c). Cooperating with medical personnel (doctors, midwives, sanitizers), for health checks. (d) Sending greeting cards for every religious holiday. e) Inviting parents to celebrate religious celebrations at school. Inviting religious leaders for preachers. f) Conducting social services in public places. f) Conducting JUMPA BERLIAN activities (Jumat Pertama Bersih Kampung - First Friday Clean Environment).

To optimize the program, the humanistic approach steps of the two principals are: (1) building cooperation with students' families in ongoing mentoring activities; (2) building a network of cooperation between schools and the community to anticipate and protect students from the dangers of drugs, traffic safety on the road, and maintain student health; (3) maintaining tolerance in the internal scope of schools, and between schools, parents and the community; (4) providing scholarship funds to students who can not 
afford; (5) caring for the natural environment; (6) living up to and practicing religious values in accordance with their respective beliefs.

The humanistic approach steps of the principals are in the form of actions of social moral ethics, joint decisions on good knowledge and not only based on assumptions, and making approaches to find meaning and purpose of cooperation with the families of students, alumni, the police, the medical team, religious leaders who care about education (Zuriah, 2008; Koesoema, 2010; Ministry of Education, 2017). Besides, the students' behavior in the middle of the community shows a peace-loving attitude; respect for brotherhood in the diversity of tribes, religions, languages, and cultures; loving the environment; fair, and good deeds (Ministry of Education and Culture, 2010). Finally, schools become a forum that provides a balance in shaping the character of students, so that the relationship between school and parents and the community is stronger (Shriner et al., 2005; Aloni, 2011). Thus, we can conclude that through the humanistic approach of the principal, the image of the school has changed meaning into a forum for empowering student characters. Schools become a conducive environment to the practice of learning to love, independence, discipline, ethical thinking, uphold the moral values of humanity, promote loyalty, responsibility, and care for others (Dantley, 2005). Koesoema, 2015).

\section{The Influence of Principal's Humanistic Contructive Actions}

Impacts of the principal's humanistic approach on the self-development program are described in the following table.

Table 1: Impacts of the Principal's Humanistic Approach on the Personal Development Program

\begin{tabular}{|c|c|c|c|}
\hline \multirow[b]{2}{*}{ No. } & \multirow[b]{2}{*}{ Forms of Principal's Humanistic Approach } & \multicolumn{2}{|c|}{ Impact } \\
\hline & & $\begin{array}{c}\text { Program for } \\
\text { Strengthening Character } \\
\text { Education }\end{array}$ & Student Character \\
\hline 01. & $\begin{array}{l}\text { Realizing cooperation in joint decision } \\
\text { making to guide and direct student behavior }\end{array}$ & $\begin{array}{l}\text { Performed optimally } \\
\text { through cooperation and } \\
\text { work based on the results } \\
\text { of joint decisions }\end{array}$ & $\begin{array}{l}\text { Order, discipline, and } \\
\text { responsible, respect } \\
\text { others, good manners, } \\
\text { love clean environment }\end{array}$ \\
\hline 02. & $\begin{array}{l}\text { Building a commitment not to disappoint self } \\
\text { and others }\end{array}$ & $\begin{array}{l}\text { Performed optimally } \\
\text { based on joint } \\
\text { commitment }\end{array}$ & $\begin{array}{l}\text { Perform behavior that } \\
\text { does not disappoint self } \\
\text { and others }\end{array}$ \\
\hline 03. & Becoming a role model & $\begin{array}{l}\text { Performed optimally } \\
\text { through self-example }\end{array}$ & $\begin{array}{l}\text { Reflect character } \\
\text { obtained from the } \\
\text { exemplary model }\end{array}$ \\
\hline 04. & $\begin{array}{l}\text { Providing counseling for students who have } \\
\text { problems with affection }\end{array}$ & $\begin{array}{l}\text { Performed optimally } \\
\text { through cooperation in } \\
\text { mentoring activities }\end{array}$ & Change of character \\
\hline
\end{tabular}

Source: results of interviews with principals, teachers, students, students' parents, document archives (presence of self-development activities, and student guidance books), and observations of student behavior in the school environment, observations of student behavior at home by parents reported during interview.

Based on the table, self-development activities were optimum. Optimization of the self-development program is reflected through the collaboration of school principals with all school components (Koesoema, 2017; Ministry of Education, 2016). The cooperation is based on the results of joint decisions, in which each element is equally responsible for their duties and roles. The principal together with the teacher and employees on duty in turns; each homeroom teacher created a daily work schedule for students, controlled student work, checked student attendance in every activity, each group was responsible for the flag ceremony activity, classroom environment, as well as lavatory and classrooms 
cleanliness and order. Also, the commitment to be a role model in behaving well (timely, appropriately attending the class, being responsible for carrying out tasks, wearing proper attire, speaking politely) is visible. Furthermore, the principal, homeroom teacher, and guidance counseling teacher succeeded in assisting problematic students, which was shown by a change in behavior in a better direction.

Personal development activities directly influence the strengthening of student character, such as Rules of entering and leaving school, responsible for assignments entrusted, disciplined in class, respecting friends, polite in speaking and dressing, favoring the clean environment, having a commitment to improving behavior (Ministry of Education, 2017).

The following table presents the impact of the principal's humanistic approach on class activities programs is explained in the following.

Table 2: Impacts of the Principal's Humanistic Approach on Class Activities

\begin{tabular}{|c|c|c|c|}
\hline \multirow[b]{2}{*}{ No. } & \multirow[b]{2}{*}{$\begin{array}{l}\text { Forms of Principal Humanistic } \\
\text { Approach }\end{array}$} & \multicolumn{2}{|c|}{ Impact } \\
\hline & & $\begin{array}{c}\text { Program for } \\
\text { Strengthening Character } \\
\text { Education } \\
\end{array}$ & Student Character \\
\hline 01. & Integrated in learning activities & & \\
\hline a. & $\begin{array}{l}\text { Conducting a meeting to prepare } \\
\text { character learning tools }\end{array}$ & $\begin{array}{l}\text { Implemented optimally by } \\
\text { involving all parties in } \\
\text { developing learning tools }\end{array}$ & - \\
\hline b. & $\begin{array}{l}\text { Entrusting parents, sharing practical } \\
\text { knowledge about good moral behavior } \\
\text { with students and scheduled school } \\
\text { authorities }\end{array}$ & $\begin{array}{l}\text { Implemented optimally by } \\
\text { involving parents in } \\
\text { guiding the student } \\
\text { character }\end{array}$ & $\begin{array}{l}\text { Perform behavior } \\
\text { according to the moral } \\
\text { life experience input } \\
\text { shared by parents }\end{array}$ \\
\hline c. & $\begin{array}{l}\text { Together with the teacher supervising } \\
\text { the pedagogical fraternity and pastoral } \\
\text { environment }\end{array}$ & $\begin{array}{l}\text { Performed optimally } \\
\text { through cooperation in the } \\
\text { presentation of material } \\
\text { together }\end{array}$ & $\begin{array}{l}\text { Discipline, responsible, } \\
\text { critical, applicable }\end{array}$ \\
\hline d. & $\begin{array}{l}\text { Supporting joint decisions in giving } \\
\text { students a final assessment }\end{array}$ & $\begin{array}{l}\text { Performed optimally } \\
\text { based on joint decisions in } \\
\text { giving the final grade of } \\
\text { students }\end{array}$ & $\begin{array}{l}\text { Balance of academic } \\
\text { competence and good } \\
\text { character }\end{array}$ \\
\hline 02. & Class management & $\begin{array}{l}\text { Run optimally based on } \\
\text { joint commitment }\end{array}$ & $\begin{array}{l}\text { Perform behavior that } \\
\text { does not disappoint self } \\
\text { and others }\end{array}$ \\
\hline & $\begin{array}{l}\text { Making a joint commitment called the } \\
\text { "bona fide" that means with good and } \\
\text { trustworthy goals, and "utilitatem" } \\
\text { (common good). }\end{array}$ & $\begin{array}{l}\text { Performed optimally by } \\
\text { building a shared } \\
\text { commitment }\end{array}$ & $\begin{array}{l}\text { Have the ability to work } \\
\text { in team, respect others's } \\
\text { thoughts, behave in an } \\
\text { ethical manner in class, } \\
\text { order, learn from one } \\
\text { another }\end{array}$ \\
\hline 03. & Learning Activities & & \\
\hline & $\begin{array}{l}\text { Learning together, and giving teachers } \\
\text { the freedom to innovate and preparing } \\
\text { evaluation time in accordance with } \\
\text { joint scheduling, to reflect on all } \\
\text { learning actions, and to ask for } \\
\text { constructive support from other } \\
\text { teachers }\end{array}$ & $\begin{array}{l}\text { Performed optimally by } \\
\text { learning together, } \\
\text { innovating, evaluating in } \\
\text { the form of reflection and } \\
\text { constructive input }\end{array}$ & $\begin{array}{l}\text { Open to innovative and } \\
\text { creative learning } \\
\text { designed by the teacher }\end{array}$ \\
\hline
\end{tabular}


The impacts of the principal's humanistic approach on classroom activities programs are: teachers have character learning tools; parents who had been appointed to share their moral lives to students cooperate well according to the schedule set by the school, which results in the internalization of moral values in students; supervision of "pedagogical fraternity" and "pastoral environment" were well performed and the results were pleasing to students; give students an objective and balanced final grade, which includes cognitive, affective, and psychomotor domains; the teacher shows the principle of "bona fide", so that the presence of the teacher pleases students, as evidenced by the acquisition of learning achievements and well behavior of the student; the teacher shows a clear commitment to realize "utilitatem" (the common good), so students feel free in expressing opinions, cooperation between students goes well, and harmony of life among students is visible; teachers are creative and innovative in applying learning models (Ministry of Education, 2017)

Class activities influence the strengthening of student characters, such as good moral life; attending the class in an appropriate manner, doing assignments with full responsibility, being critical in asking questions and discussion, building an applicable mindset; building a balanced development between academic competence and good character; behaving in a way that does not disappoint self and others; being able to work together, respecting others' thoughts, behaving in an ethical manner in class, order, learning from one another; being open and ready to follow innovative and creative learning designed by teachers (Ministry of Education, 2017).

The following table presents the impact of the humanistic approach of the two principals in building positive school culture.

Table 3: Impacts of the Principal's Humanistic Approach in building School Culture

\begin{tabular}{|c|c|c|c|}
\hline \multirow[b]{2}{*}{ No. } & \multirow[b]{2}{*}{$\begin{array}{l}\text { Forms of Principal Humanistic } \\
\text { Approach }\end{array}$} & \multicolumn{2}{|l|}{ Impact } \\
\hline & & $\begin{array}{l}\text { Program for Strengthening } \\
\text { Character Education }\end{array}$ & $\begin{array}{l}\text { Strengthening of } \\
\text { Student Character }\end{array}$ \\
\hline 01. & $\begin{array}{l}\text { Performing joint decisions by } \\
\text { coordinating each activity }\end{array}$ & $\begin{array}{l}\text { Performed optimally based on } \\
\text { joint decisions, to organize } \\
\text { activities }\end{array}$ & $\begin{array}{l}\text { Cooperation, } \\
\text { responsible }\end{array}$ \\
\hline 02. & Entrusting team work & $\begin{array}{l}\text { Performed optimally in the } \\
\text { spirit of mutual trust in } \\
\text { teamwork }\end{array}$ & $\begin{array}{l}\text { believe in self and } \\
\text { others, take } \\
\text { responsibility }\end{array}$ \\
\hline 03. & $\begin{array}{l}\text { Cultivating the spirit of } \\
\text { cooperation between work teams }\end{array}$ & $\begin{array}{l}\text { In an on going process } \\
\text { through collaboration between } \\
\text { teamwork }\end{array}$ & Cooperation \\
\hline 04. & Persuasive communication & $\begin{array}{l}\text { Performed optimally through } \\
\text { persuasive communication }\end{array}$ & Open in the community \\
\hline 05. & $\begin{array}{l}\text { Supporting and being engaged in } \\
\text { activities }\end{array}$ & $\begin{array}{l}\text { Performed optimally through } \\
\text { support and involvement }\end{array}$ & Respect togetherness \\
\hline 06. & Cultivating the values of faith & $\begin{array}{l}\text { Performed optimally in } \\
\text { various spiritual activities }\end{array}$ & Have faith and piety \\
\hline 07 & $\begin{array}{l}\text { Building self-sensitivity and } \\
\text { being solider }\end{array}$ & $\begin{array}{l}\text { Performed optimally by } \\
\text { arousing self-sensitivity to } \\
\text { solidify with others }\end{array}$ & $\begin{array}{l}\text { Sensitive and solid with } \\
\text { others }\end{array}$ \\
\hline 08. & $\begin{array}{l}\text { Promoting the spirit of } \\
\text { democracy }\end{array}$ & $\begin{array}{l}\text { Implemented optimally } \\
\text { through the inculcation of } \\
\text { democratic values }\end{array}$ & Democracy \\
\hline 09. & Holding alumni gathering & $\begin{array}{l}\text { Performed optimally by } \\
\text { fostering togetherness }\end{array}$ & Adaptation \\
\hline 10. & Cultivating honesty values & $\begin{array}{l}\text { Performed optimally through } \\
\text { the planting of honesty values }\end{array}$ & Honesty \\
\hline 11. & Conducting joint evaluation & Performed optimally through & Reflective, and \\
\hline
\end{tabular}


evaluation to reflect and internalize the meaning of

understand self-respect each activity carried out

Source: results of interviews with principals, teachers, students, parents, school committees, school supervisors, document archives (decree letters, memorandum of understanding, school strategic plans), and observations of student behavior in the classroom

The humanistic approach has positive impacts in optimizing character-building programs in the school environment, such as well-organized extracurricular activities; the creation of a spirit of cooperation among teamwork so that it is solid and responsible at work; persuasive communication between school principals, teachers, staff, school committees, parents, and the community; all parties support each other and get involved in every activity; the values of faith are getting strong and resilient; all school components have awareness and sensitivity to help each other, both related to learning activities as well as other interests; the spirit of high democratic life; establishment of cooperation between schools and alumni to think about and build a better quality of education; Evaluation activities are going well to reflect and internalize the meaning of each activity performed (Koesoema, 2016; Ministry of Education, 2016).

Activities in school environment influence the strengthening of student character such as; being able to perform collaboration; being responsible with the task, believing in yourself and others, being easy to get along and open; respecting for togetherness, having faith and piety, having sensitivity and solidarity with others, having the spirit of democracy, showing adaptability; honesty, reflective and self-respecting behavior (Koesoema, 2017; Ministry of Education, 2017).

The following table describes the impact of the two principals' humanistic approach in optimizing activities in the community.

Table 4: Impacts of the Principal's Humanistic Approach on Activities in the Community Environment

\begin{tabular}{|c|c|c|c|}
\hline \multirow[b]{2}{*}{ No. } & \multirow{2}{*}{$\begin{array}{l}\text { Forms of Principal Humanistic } \\
\text { Approach }\end{array}$} & \multicolumn{2}{|l|}{ Impact } \\
\hline & & $\begin{array}{l}\text { Program for Strengthening } \\
\text { Character Education }\end{array}$ & $\begin{array}{c}\text { Strengthening of } \\
\text { Student Character }\end{array}$ \\
\hline 01. & $\begin{array}{l}\text { Establishing cooperation with } \\
\text { student families }\end{array}$ & $\begin{array}{l}\text { Performed optimally through } \\
\text { home visits of students' } \\
\text { parents }\end{array}$ & An open individual \\
\hline 02. & Providing scholarship funds & $\begin{array}{l}\text { Performed optimally through } \\
\text { fundraising from the } \\
\text { government, alumni, and } \\
\text { school foundations }\end{array}$ & $\begin{array}{l}\text { Sensitive, and have a } \\
\text { passion for } \\
\text { achievement }\end{array}$ \\
\hline 02. & $\begin{array}{l}\text { Establishing cooperation with } \\
\text { the police }\end{array}$ & $\begin{array}{l}\text { Performed optimally through } \\
\text { providing materials of the } \\
\text { dangers of drugs and orderly } \\
\text { traffic by the police }\end{array}$ & $\begin{array}{l}\text { Free from drugs and } \\
\text { has an orderly traffic }\end{array}$ \\
\hline 03. & $\begin{array}{l}\text { Establishing cooperation with } \\
\text { the medical team }\end{array}$ & $\begin{array}{l}\text { Performed optimally through } \\
\text { health inspection activities }\end{array}$ & Healthy \\
\hline 04. & $\begin{array}{l}\text { Maintaining tolerant atmosphere } \\
\text { in scope }\end{array}$ & $\begin{array}{l}\text { Performed optimally through } \\
\text { sending greeting cards, and } \\
\text { religious celebrations at } \\
\text { school }\end{array}$ & Tolerant \\
\hline 05. & $\begin{array}{l}\text { Cultivating the habit of } \\
\text { maintaining a clean school } \\
\text { environment }\end{array}$ & $\begin{array}{l}\text { Performed optimally through } \\
\text { Jumat Bersih activities }\end{array}$ & $\begin{array}{l}\text { Love clean } \\
\text { environment }\end{array}$ \\
\hline 06. & $\begin{array}{l}\text { Living and practicing religious } \\
\text { values }\end{array}$ & $\begin{array}{l}\text { Performed optimally through } \\
\text { the sharing of coaching } \\
\text { activities, and religious }\end{array}$ & Have faith and be pious \\
\hline
\end{tabular}




\begin{tabular}{llll}
\hline & celebrations & \\
\hline 07. Cultivating the values of faith & $\begin{array}{l}\text { Performed optimally in } \\
\text { various spiritual activities }\end{array}$ & Have faith and piety \\
\hline
\end{tabular}

Source: results of interviews with the principal, teachers, students, parents, school committee, document archives (invitation letter to the police, the medical team, guest book, schedule and family visit letter)

The humanistic approach has positive impacts in optimizing the character-building program in the community, such as cooperation with parents in scheduled home visits are running well, and building a sense of kinship; every semester the school announced names of students who receive scholarships from government, alumni, and school foundations; there were no cases of drug use, and there were no reports from the public and the police to the school regarding the traffic violations committed by students; students lived healthily; the atmosphere of tolerance was very harmonious; school environment was clean and tidy; every activity of fostering and religious celebrations were well implemented; student faith was built (Koesoema, 2016; Ministry of Education, 2017).

Activities in the community influenced the strengthening of student character, such as: create an individual who is open, sensitive, drug free, drive safely, has a spirit of struggle to pursue achievement, knows how to take care of him/herself, loves religious tolerance, favors a clean environment, has noble and pious religious character (Ministry of Education, 2017)

\section{Conclusion}

Based on the findings and discussion and in the light of recent research, it shows that the humanistic approach dimension of the principal's leadership comes from personal excellence (integrity, wholeness, self-authenticity) that appears in an open attitude, existentialism in new experiences, consistency, flexibility, creative and constructive, and reviving the inspiring humanist spirituality of figures. Based on personal excellence and the appreciation of this humanist spirituality, the humanistic approach of the principal's leadership focuses on unconditional respect for the human dignity of all school components, ethical reflection integrated into decision making, normative legitimacy in taking action and decisions within the educational organization. These three humanistic dimensions are an integral part of moral imagination.

Implementation of the principal's humanistic approach has positive impacts in optimizing the implementation of the program for strengthening character education in the form of personal development activities, classroom activities, activities within the school environment, and activities in the community. All these activities influence the strengthening of student character. Thus, the image of school has changed into a forum for empowering human beings and their characters. A school is a place that provides a balance of student character (individual learning and group learning, analytic thinking and intuitive thinking, content, and process, as well as meaningful learning and assessment).

\section{References}

Acevedo, A. (2011). Personalist Business Ethics and Humanistic Management: Insights from Jacques Maritain. Journal of Business Ethics, 105(2), 197-219. doi:10.1007/s10551-011-0959-x

Aktouf, O., \& Holford, W. D. (2009). The Implications of Humanism for Business Studies. In H. Spitzeck, M. Pirson, W. Amann, S. Khan, \& E. von Kimakowitz, Humanism in Business (101-122). Cambridge: Cambridge University Press 
Aloni, N. (2011). Humanistic Education: From Theory to Practice. In W. Veugelers (Ed.), Education and Humanism: Linking Autonomy And Humanity (pp. 35-46). Rotterdam, Netherlands: Sense Publishers.

Altheide, D. L., \& Johnson, J. M. (2000). Criteria for Assessing the Validity of Interpretation in Qualitative Research. in Denzin, N. K., \& Lincoln, Yv. S. (Ed.), Handbook Qualitative Research. (2Ed.), California: Sage Publition, Inc.

Ashmos, D. P., \& Duchon, D. (2000). Spirituality at Work. Journal of Management Inquiry, 9(2), 134-145.

Barrick, M. R., Mount, M. K., \& Gupta, R. (2003). Meta-Analysis of the Relationship Between the Five-Factor Model of Personality and Holland's Occupational Types. Personnel Psychology, 56(1), 45-75

Blanchard, S. Essary V., Zigarmi, D., \& Houson, S. (2006). The leadership-Profit Chain. Defining the importance of Leadership Capacity. The Ken Blanchard Companies. Global Head Quarter. www.kenblanchard.com (29 Jan 2019)

Blickle, G., Meurs, J. A., Wihler, A., Ewen, C., Merkl, R., \& Missfeld, T. (2015). Extraversion and Job Performance: How Context Relevance and Bandwidth Specificity Create a Non-Linear, Positive, and Asymptotic Relationship. Journal of Vocational Behavior, 87, 80-88.

Bierly, P., Kessler, E., \& Christensen, E. (2000). Organizational Learning, Knowledge and Wisdom. Journal of Organizational Change Management, 13(6), 595-618.

Bogdan, R., C. dan Biklen, S. K. (1998). Qualitatif Research for Education: An Introduction To Theory And Methods. Boston: Allyn and Bacon.Inc.

Byrne, K. A., Silasi-Mansat, C. D., \& Worthy, D. A. (2015). Who Chokes Under Pressure? The Big Five Personality Traits and Decision-Making Under Pressure. Personality and Individual Differences, 74, 22-28.

Cavanagh, G., Hanson, B., Hanson, K., \& Hinojoso, J. (2001). Toward a Spirituality for the Contemporary Organization: Implications for Work, Family and Society, in Champoux, J.E. (2000). Organizational Behavior: Essential Tenets for A NeW Millennium. South-Western College Publishing, Cincinatti

Colbert, B. A., Nicholson, J., \& Kurucz, E. C. (2018). Humanistic Leadership for Sustainable Transformation. Evolving Leadership for Collective Wellbeing, 33-47.

Cook, L. A., Smith, W. S., Lan, W. Y., \& Carpenter, D. (2016). The Development of Global Competencies and Global Mindedness Through Global Education Experiences. International Journal of Global Education, 5 (2) 1-15

Creswell, J. W. (2009). Research Design. Qualitative, Quantitative, and Mixed Method Approaches. Los Angeles: SAGE Publications, Inc.

Davila, A., \& Elvira, M. M. (2012). Humanistic Leadership: Lessons From Latin America. Journal of World Business, 47(4), 548-554.

DeCavalho, R. J. (1991). The humanistic Paradigm in Education. The Humanistic Psychologist, 19(1), 88-104.

Dehler, G. E., \& Welsh, M. A. (1994). Spirituality and Organizational Transformation: Implications for The New Management Paradigm. Journal of Managerial Psychology, 9, 17-26.

De Groot, M. B. A. Language And Cognition In Bilinguals And Multilinguals: An Introduction. New York, Psychology Press. 2011. Pp. Vii, 514

Denzin, N. K., \& Lincoln, Yv., S. (2000). Handbook of Qualitative Research (Eds.). California: Sage Publication, Inc.

Dewantara, Ki H. (1977). Education. Yogyakarta: The Noble Assembly of Taman Students Association 
Dierksmeier, C. (2016). What is 'Humanistic' About Humanistic Management?. Humanist Management Journal, 1, 9-32

Dohmen, J. (2003). Philosophers on the 'Art of Living'. Journal Of Happiness Studies, 4(4), 351-371.

Endah, S. ( 2012). Implementation of the Character Education Curriculum. Yogyakarta: Citra Aji Parama

Flake, C. L. (2000). Holistic Education: Principles, Perspectives, and Practice. Brandon, VT: Holistic Education Press.

Fry, L. W. (2003). Toward a theory of spiritual leadership. The leadership quarterly, 14(6), 693-728.

Fry, L., \& Slocum, J. (2008). Maximizing the Triple Bottom Line Through A Strategic Scorecard Business Model of Spiritual Leadership. Organizational Dynamics, 31(1), 86-96.

Gage, N., \& Berliner, D. (1991). Educational Psychology (5th ed.). Boston: Houghton, Mifflin.

Giddens, A. (2003). Runaway World: How Globalization is Reshaping Our Lives. Washington, DC: Taylor \& Francis

Government Regulation (PP) No. 87 of 2017 concerning Strengthening Character Education

Haynes, K.T., Hitt, M.A., \& Campbell, J.T. (2015), The Dark Side of Leadership: Toward a Midrange Theory of Hubris and Greed in Entrepreneurial Contexts. Journal of Management Studies, 52, 479-505.

Higgs, J., Horsfall, D., \& Grace, S. (Eds.). (2009). Writing Qualitative Research on Practice. Rotterdam: Sense. Chapter collection of writing up research; includes excellent chapters on question development, argument construction, and genres (narrative inquiry, arts-based research, etc.).

Holy Bible. (2011). Genesis 1:27 New International Version (NIV). by Biblica, Inc. https://www.biblegateway.com/passage/?search=Genesis, accessed on July 20, 2019

Holy Bible. (2011). John 15:4 New International Version (NIV). by Biblica, Inc. https://www.biblegateway.com/passage/?search=John, accessed on July 20, 2019

Jingna, D. (2012). Application of Humanism Theory in the Teaching Approach. Higher Education of Social Science, 3(1), 32-36

Kasali, R. (2017). Disruption: Nothing Can Be Changed Before Motivation Is Not Enough. Jakarta: Gramedia Pustaka Utama

Koesoema, D. A. (2010). Character Education: Strategies to Educate Children in the Global Age. Jakarta: Grasindo

Koesoema, D. A. (2015). Character Education Strategy, Mental Revolution in Educational Institutions. Yogyakarta: Kanisius

Konz, G. \& Ryan, F. (1999). Maintaining an organizational spirituality: No easy task. Journal of Organizational Change Management, 12(3), 200-210.

Leutner, F., Ahmetoglu, G., Akhtar, R., \& Chamorro-Premuzic, T. (2014). The Relationship Between The Entrepreneurial Personality and The Big Five Personality Traits. Personality and Individual Differences, 63, 58-63.

Li, Y. (2013). Cultivating student global competence: A pilot experimental study. Decision Sciences Journal of Innovative Education, 11(1), 125-143.

Lickona, T. (2012). Education for Character: Mendidik untuk Membentuk Karakter. Jakarta: PT Bumi Aksara.

Lovvorn, Al S. \& Chen, Jiun-Shiu. (2011). Developing a Global Mindset: The Relationship between an International Assignment and Cultural Intelligence. International Journal of Business and Social Science, 2 (9) 275-283 
Maslow, A. (1969). New introduction: Religions, Values, and Peak-Experiences. Journal of Transpersonal Psychology, 1(1), 83-90.

Melé, D. (2016). Understanding Humanistic Management. Humanistic Management Journal, 1(1), 33-55.

Miles, M., B., Huberman, A., M., \& Saldaña, J. (2014). Qualitative Data Analysis: a Methods Sourcebook. (Third Edition). Arizona State University: SAGE Publications, Inc.

Mutrofin. (2007). Autocritical Education; Evaluative Ideas. Yogyakarta: LaksBang PRESSindo

Nava, R, G. (2001). Holistic Education: Pedagogy of Universal Love. Brandon: Holistic education press

Nemiroff, G. H. (1992). Reconstructing Education: Toward a Pedagogy of Critical Humanism. New York, NY: Bergin \& Garvey

Nida-Rümelin, J. (2009). Philosophical Grounds of Humanism in Economics. In H. Spitzeck, M. Pirson, W. Amann, S. Khan \& E. von Kimakowitz (Eds.), Humanism in Business (pp. 15-25). Cambridge: Cambridge University Press.

Paloutzian, R. F. (1996). Invitation to the Psychology of Religion. (2nd ed). Boston: Allyn \& Bacon.

Patteron, C. H. (1987). What Has Happened to Humanistic Education? Michigan Journal of Counseling and Development, 18 (1), 8-10.

Peus, C., \& Frey, D. (2009). Humanism at Work: Crucial Organizational Cultures and Leadership Principles. In H. Spitzeck, M. Pirson, W. Amann, S. Khan, \& E. Von Kimakowitz, Humanism in Business (pp. 260-277). Cambridge: Cambridge University Press

Pirson, M. (2017). Editorial: Welcome to the Humanistic Management Journal. Humanistic Management Journal, 1(1), 17.

Robbins. I. (2002) From the Academy of Management's August 5, 2003, Management, Spirituality, and Religion Interest Group's Proposed Minutes (pp.5-39).

Rodriguez-Lluesma, C., Davila, A., \& Elvira, M. M. (2014). Humanistic Leadership as a Value-Infused Dialogue of Global Leaders and Local Stakeholders. In N. C. Lupton, \& M. Pirson. Humanistic Perspectives on International Business and Management. (81-91). Basingstoke: Palgrave Macmillan UK

Rogers, C., \& Freiberg, H. J. (1994). Freedom To Learn (3rd ed.). New York: Macmillan/Merrill.

Sahenk, S. S. (2010). Characteristics of The Headmasters, Teachers, and Students in an Effective School. Innovation and Creativity in Education, 2(2), 4298-4304.

Sass, J. S. (2000). Characterizing Organizational Spirituality: An Organizational Communication Culture Approach. Communication Studies, 51, 195-207.

Shriner, P., Banev, S., \& Oxly, S. (2005). Holistic Education Resource Book. Verlage: Waxmann

Solaja, O. M., Idowu, F. E., \& James, A. E. (2016). Exploring the relationship between leadership communication style, personality trait and organizational productivity. Serbian Journal of Management, 11(1), 99-117.

Stiefel, R. T. (1975). Towards a More Humanistic Approach in Management Education. Management Education and Development, 6(3), 156-165.

Strack, G, Fottler, M., Wheatley,M., \&Sodomka, P.(2002). Spirituality and effective leadership in healthcare: Is there a connection? Frontiers of Health Service Management, 18(4), 3-45. 
The Ministry of Education and Culture. (2010). Development of National Culture and Character Education. Jakarta: Secretariat of the Curriculum Research and Development Center

The Ministry of Education and Culture. (2016). Guidelines for Strengthening Character Education. Jakarta: Secretariat Team for Strengthening Character Education

Ministry of Education and Culture. (2017). Strengthening Character Education; Training Module for Principals. Jakarta: Secretariat Team Strengthening Character Education

UNESCO (2012). Education Sustainable Development. Sourcebook. Paris France: the United Nations Educational, Scientific and Cultural Organization Publication.

Uno, H., B. (2008). Educational Profession, Problems, Solutions, and Educational Reform in Indonesia. Jakarta: PT Bumi Aksara

Veugelers, W. (2007). Creating Critical-Democratic Citizenship Education: Empowering Humanity and Democracy in Dutch Education. Compare, 37(1), 105-119.

Veugelers, W. (Eds.). (2008). Getting involved. Global citizenship development and sources of moral values. In Education and Humanism; Linking Autonomy and Humanity,

$\mathrm{AW}$

Rotterdam,TheNetherlands:www.sensepublishers.com.peter.deliefde@sensepublishe rsc.om

Waddock, S. (2016). Developing Humanistic Leadership Education. Humanist Management Journal, 1, 57-73

Wahjumisumidjo.(1999). Principal Leadership, Theoretical Review and Problems. Jakarta: Raja Grafindo Persada

Werhane, P. H. (2002). Moral Imagination and Systems Thinking. Journal of Business Ethics, 38: 33-42.

Werhane, P. H. (2008). Mental Models, Moral Imagination and System Thinking in the Age of Globalization. Journal of Business Ethics, 78, 463-474.

Westheimer, J. (2011). Practicing democracy. In W. Veugelers (Ed.), Education and humanism: Linking Autonomy and Humanity, (95-103). Rotterdam, Netherlands: Sense Publishers.

Zuchdi, D. (2008). Humanization of Education. Jakarta: PT. Bumi Aksara

Yin, R. K. (2017). Case study research and applications: Design and methods. London: Sage publications. 